\title{
Environmental Assets and Expenses Accounting as an Indicator of Social Responsibility in Spanish Energy Companies on the IBEX 35
}

\author{
DOI: http://dx.doi.org/10.12775/JCRL.2019.007 \\ MARIPAZ MUÑOZ PRIETO \\ Catholic University of Avila, Ávila, Spain \\ e-mail: maripaz@ucavila.es
}

\begin{abstract}
Purpose: The aim is to prove that traditional accounting does not have the ability to report, in a clear and reliable way, through its financial statements, the environmental activities performed by the companies, hindering their commitment to corporate social responsibility.

Design / methodology / approach: This is a qualitative and quantitative study, of a documentary design, of a descriptive type, using the bibliographic review of primary sources and the financial analysis of the annual accounts and management reports of energy companies in a period of 10 years.

Findings: Accounting, which gathers the records of economic and social issues, cannot neglect current environmental problems. Companies should seek solutions to improve collection and presentation of environmental information in their financial statements, helping to minimize the environmental impacts caused by their production systems and become socially responsible companies. Current accounting systems are not able to reflect the environmental reality of companies, and therefore cannot be used for decision-making in the environmental field.

Originality / value: The study shows that the analysed energy companies do not devote enough effort to the environment or their accounting systems do not sufficiently inform about taken actions. Nevertheless,
\end{abstract}


a positive trend in their investments and expenditures on the environment manifesting their commitment to social responsibility is observed.

Paper type: Article.

Keywords: Environmental assets, environmental expenses, environmental accounting, corporate social responsibility, energy companies.

\section{Introduction}

All economic-based human activities are based on a relationship between society and nature, and this has led to the fact that, in recent decades, the scope and scale of environmental problems have grown considerably (pollution, deforestation, change climate...). Unfortunately, in most cases, companies do not provide information that makes visible the total costs and impacts they incur during their processes (Mejia Soto, 2010).

This concern for social and environmental issues has been reflected in recent years in the implementation, by companies, of corporate social responsibility strategies. Corporate social responsibility recognizes four strategic lines which are (Cajiga, 2013): the ethics and corporate governance, the quality of life in the company, the connection and commitment to the community and the care and preservation of the environment (Pérez Espinoza et al., 2016). This makes the environmental issue one of the important lines to know the commitment of companies to their corporate social responsibility.

The latest studies carried out in Spanish energy companies, among which we can cite the works of Lasierra Asún (2019), Toribios Plaza (2019), Garcia Garcia (2014) and González Bonilla (2017), show that companies focus on the information about corporate social responsibility in its sustainability reports. Nevertheless, according to Domínguez Churruca (2014), the most influential energy companies with the highest volume of business in Spain did not publish enough information about environmental aspects in the period 2003-2012.

Considering the above, traditional accounting should be an effective tool to record this information but, in reality, it does not have adequate instruments to recognize the environmental problems, that is why profound conceptual, epistemological and theoretical transformations are necessary (Guevara and Galvis, 2019). The financial statements with environmental data, translate into monetary terms what the company 
has invested to be socially responsible, allowing them to have some advantages (Vicuña et al., 2020).

The main objective of this article is to verify that the current financial accounting is not able to collect, measure and report through the financial statements, in a reliable and clear way of the results and relationships that the company has with the environment. Therefore, the company will not be able to use this information effectively for decision-making, or to develop an appropriate strategy of environmental corporate social responsibility. It also aims to verify the change in trends in these companies, and possible improvements in the amounts of environmental investments and expenses.

The results of this study will make it possible to show that an adequate use of environmental accounting would allow companies to obtain more advantages than disadvantages. These advantages range from improvements in profits through cost reduction, improvement in processes by reducing waste generation or improving the use of resources, detection of critical areas, provision of quality information to stakeholders or a better public image.

\section{Materials and methods}

In regard to the methodology used, this is a qualitative and quantitative study, of a documentary design, of a descriptive type, using the bibliographic review of primary sources and the financial analysis of the annual accounts and management reports of energy companies in a period of 10 years (2008-2017), obtained from the CNMV website in the digital format. For the development of the study, the following selection criteria have been used:

(1) companies of the IBEX 35 as they have a greater level of disclosure of finance and non-financial information;

(2) industries called dangerous for the environment. The chosen sectors have been the Energy and Petroleum, which are made up of the following 7 companies:

a. Subsector 1.1. Petroleum:

- REPSOL SA,

b. Subsector 1.2. Electricity and Gas:

- ENAGAS SA,

- ENDESA SA, 
- GAS NATURAL SA / NATURGY,

- IBERDROLA SA,

c. Subsector 1.4. Renewable energy:

- AUDAX RENOVABLES SA,

- SOLARIA ENERGIA Y MEDIO AMBIENTE SA.

The energy sector must meet environmental objectives at the same time as economic and social objectives, through introducing new technologies and energies that favour sustainability (Lasierra Asún, 2019). We are going to look at the information that companies publish about assets of an environmental nature and mainly about environmental assets and expenses. Some of these companies do not provide such information, but it has been decided to include them because it is important to know if the information is provided or not, as their level of transparency.

\section{Definition and registration of environmental assets}

First, we will analyze how the accounting regulations define and regulate registration of environmental assets. Environmental assets are defined in the ICAC Resolution (2002, p. 12833) as those elements incorporated into the entity's assets "in order to be used in a lasting manner in its activity, the main purpose of which is to minimize the impact and the protection and improvement of the environment, including the reduction or elimination of future contamination from the Entity's operations”. These assets will be accounted for in the corresponding items of group B) Fixed Assets, within the assets of the balance sheet.

The registration criteria established by the ICAC Resolution (2002) is as follows: "They are recorded in the corresponding items of Tangible and Intangible Assets, according to their nature, valued at their acquisition price or production cost and being amortized linearly over the years of useful life".

\section{Environmental assets in the companies under the study}

Firstly, we are going to check if the treatment that companies make of environmental assets, their definition and the registration criteria used 
by these companies are adapted to the current regulations set out above. The source of the definitions is the annual report of each company. All the companies under the study used the definitions of environmental assets as well as the registration criteria provided by the Resolution (ICAC, 2002) almost literally. Detailed analysis of treatment of information on environmental assets in the studied companies is presented in Table 1.

Table 1. Treatment of information on environmental assets in the companies under the study

\begin{tabular}{lccc}
\hline & Definition & $\begin{array}{l}\text { Recognition } \\
\text { criteria }\end{array}$ & $\begin{array}{l}\text { Annual } \\
\text { amounts }\end{array}$ \\
\hline REPSOL & $\mathrm{x}$ & $\mathrm{x}$ & $\mathrm{x}$ \\
\hline ENAGAS & $\mathrm{x}$ & $\mathrm{x}$ & $\mathrm{x}$ \\
\hline ENDESA & $\mathrm{x}$ & $\mathrm{x}$ & $\mathrm{x}$ \\
\hline NATURGY & $\mathrm{x}$ & $\mathrm{x}$ & \\
\hline IBERDROLA & $\mathrm{x}$ & & \\
\hline AUDAX & & $\mathrm{x}$ & \\
\hline SOLARIA & $\mathrm{x}$ & &
\end{tabular}

Source: own elaboration.

The annual reports and management reports of the companies have also been analyzed to obtain the required amounts. To establish a comparative measure, we used the total amount of fixed assets and the environmental assets to be able to calculate the percentage within each of these items and make comparable amounts between companies.

(1) REPSOL: in its annual reports and management reports, the company reports extensively on environmental projects and amounts on environmental assets in each of the years (cf. Table 2).

The environmental investments show a growing trend in the first 4 years of the analyzed period of time, to later withstand a significant drop in 2012 and follow a slow growth trend throughout the rest of the period (cf. Figure 1a). If we graphically represent the data regarding the total fixed assets, we can observe a peak, due to a fall in the amount of the company's total fixed assets, but not a rise in absolute terms of environmental investments, so it is considered a change punctual trend. If we represent environmental investment with respect to total assets, 
Table 2. Environmental assets of the REPSOL group [millions of euro]

\begin{tabular}{llllllllllll}
\hline & $\mathbf{2 0 0 8}$ & $\mathbf{2 0 0 9}$ & $\mathbf{2 0 1 0}$ & $\mathbf{2 0 1 1}$ & $\mathbf{2 0 1 2}$ & $\mathbf{2 0 1 3}$ & $\mathbf{2 0 1 4}$ & $\mathbf{2 0 1 5}$ & $\mathbf{2 0 1 6}$ & $\mathbf{2 0 1 7}$ & Average \\
\hline $\begin{array}{l}\text { Environmental } \\
\text { assets }\end{array}$ & 3,390 & 3,793 & 3,989 & 4,588 & 3,244 & 3,435 & 3,260 & 3,642 & 3,830 & 3,939 & 3,711 \\
\hline $\begin{array}{l}\text { Total fixed } \\
\text { assets }\end{array}$ & 29,816 & 38,718 & 41,003 & 44,542 & 33,741 & 31,569 & 19,000 & 32,959 & 32,406 & 29,184 & 33,294 \\
\hline$\%$ & 11.37 & 9.80 & 9.73 & 10.30 & 9.61 & 10.88 & 17.16 & 11.05 & 11.82 & 13.50 & 11.15 \\
\hline Total asset & 49,429 & 58,083 & 67,631 & 70,957 & 64,921 & 65,086 & 51,889 & 63,077 & 64,849 & 59,857 & 61,578 \\
\hline$\%$ & 6.86 & 6.53 & 5.90 & 6.47 & 5.00 & 5.28 & 6.28 & 5.77 & 5.91 & 6.58 & 6.03 \\
\hline
\end{tabular}

Source: own elaboration

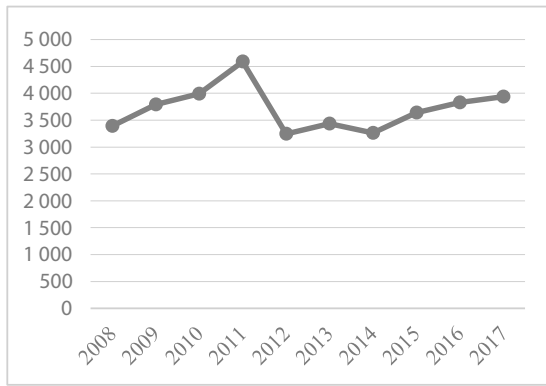

(a)

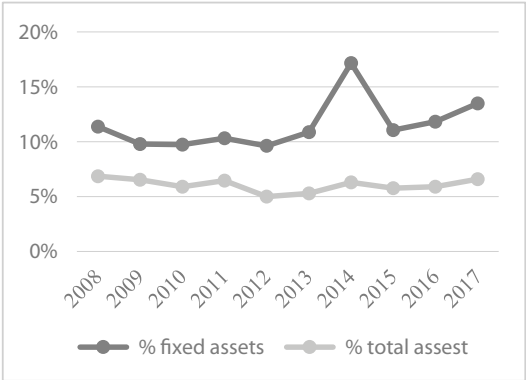

(b)

Figure 1 (a) Environmental assets in REPSOL [millions of euro]; (b) Environmental assets as percentages of total fixed assets and total assets of REPSOL

Source: own elaboration.

we notice that it decreases slightly but maintains a fairly homogeneous trend (cf. Figure 1b).

(2) ENAGAS: we can also find information about the company's environmental projects in addition to providing the quantitative data (cf. Table 3).

In regard to environmental investments of the ENAGAS group, the downward trend in noticed. Although it has slight rebounds, but the fall in investment has been significant (cf. Figure 2a). If we graphically represent the data regarding the group's total fixed assets or total assets, we can see that the graph is practically the same as the representation of the company's environmental investment, observing a general decreasing trend (cf. Figure 2b). 
Table 3. Environmental investments of the ENAGAS group [thousands of euro]

\begin{tabular}{llllllllllll}
\hline & $\mathbf{2 0 0 8}$ & $\mathbf{2 0 0 9}$ & $\mathbf{2 0 1 0}$ & $\mathbf{2 0 1 1}$ & $\mathbf{2 0 1 2}$ & $\mathbf{2 0 1 3}$ & $\mathbf{2 0 1 4}$ & $\mathbf{2 0 1 5}$ & $\mathbf{2 0 1 6}$ & $\mathbf{2 0 1 7}$ & Average \\
\hline $\begin{array}{l}\text { Environmental } \\
\text { assets }\end{array}$ & 54,644 & 35,088 & 38,777 & 23,259 & 22,342 & 9,286 & 8,573 & 29,440 & 11,084 & 5,288 & 23,778 \\
\hline $\begin{array}{l}\text { Total fixed } \\
\text { assets }\end{array}$ & $3,975,029$ & $4,654,955$ & $5,123,748$ & $5,580,070$ & $5,679,516$ & $5,784,405$ & $5,336,848$ & $5,183,400$ & $5,002,887$ & $5,501,351$ & $5,182,221$ \\
\hline$\%$ & 1.37 & 0.75 & 0.76 & 0.42 & 0.39 & 0.16 & 0.16 & 0.57 & 0.22 & 0.10 & 0.46 \\
\hline Total asset & $4,717,826$ & $5,779,939$ & $6,829,136$ & $7,717,399$ & $8,083,443$ & $7,210,600$ & $7,711,859$ & $7,751,918$ & $9,247,967$ & $9,572,636$ & $7,462,272$ \\
\hline$\%$ & 1.16 & 0.61 & 0.57 & 0.30 & 0.28 & 0.13 & 0.11 & 0.38 & 0.12 & 0.06 & 0.32 \\
\hline
\end{tabular}

Source: own elaboration.

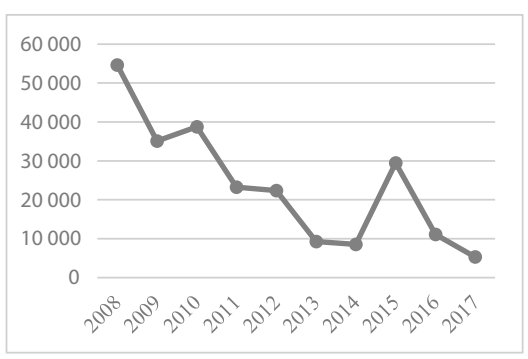

(a)

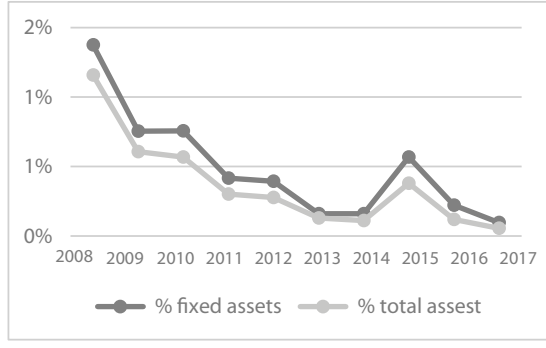

(b)

Figure 2. (a) Environmental assets of ENAGAS [thousands of euro];

(b) Environmental assets as percentages of fixed assets and total assets of ENAGAS Source: own elaboration.

(3) ENDESA: Although no specific projects are reported, the consolidated annual report provides information about the amounts of environmental investments (cf. Table 4).

Table 4. Environmental investments of the ENDESA group [millions of euro]

\begin{tabular}{llllllllllll}
\hline & $\mathbf{2 0 0 8}$ & $\mathbf{2 0 0 9}$ & $\mathbf{2 0 1 0}$ & $\mathbf{2 0 1 1}$ & $\mathbf{2 0 1 2}$ & $\mathbf{2 0 1 3}$ & $\mathbf{2 0 1 4}$ & $\mathbf{2 0 1 5}$ & $\mathbf{2 0 1 6}$ & $\mathbf{2 0 1 7}$ & Average \\
\hline $\begin{array}{l}\text { Environmental } \\
\text { assets }\end{array}$ & - & 20 & 20 & 41 & 70 & 86 & 113 & 84 & 108 & 110 & 72.44 \\
\hline $\begin{array}{l}\text { Total fixed } \\
\text { assets }\end{array}$ & 31,528 & 35,059 & 32,896 & 32,904 & 34,106 & 32,053 & 21,104 & 20,815 & 21,891 & 21,727 & 28,062 \\
\hline$\%$ & - & 0.06 & 0.06 & 0.12 & 0.21 & 0.27 & 0.54 & 0.40 & 0.49 & 0.51 & 0.26 \\
\hline Total assets & 58,546 & 60,195 & 62,588 & 58,721 & 58,778 & 56,457 & 30,696 & 29,245 & 30,964 & 31,037 & 46,520 \\
\hline$\%$ & - & 0.03 & 0.03 & 0.07 & 0.12 & 0.15 & 0.37 & 0.29 & 0.35 & 0.35 & 0.16 \\
\hline
\end{tabular}

Source: own elaboration. 


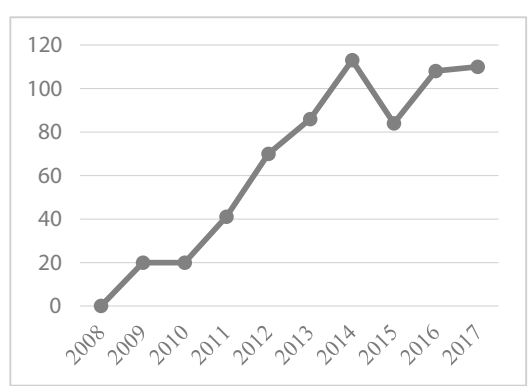

(a)

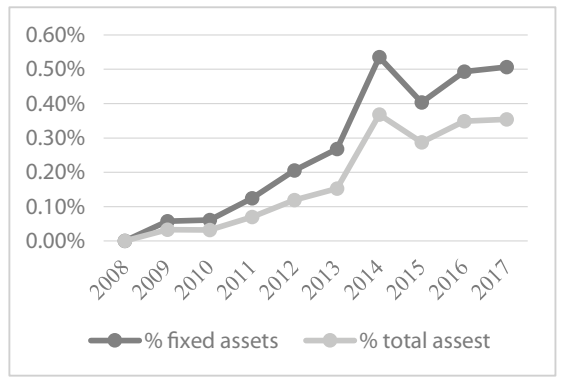

(b)

Figure 3. (a) Environmental assets of ENDESA [millions of euro]; (b) Environmental assets as percentages of fixed assets and total assets of ENDESA Source: own elaboration.

In the graphical representation of the amount of environmental assets, we can observe how the company has been increasing them over the years 2008-2015, stabilizing them in 2016-2017 (cf. Figure 3a). If we establish the comparison with the amounts of the tangible fixed assets of the group or with the total assets, this graph also follows a clearly increasing trend quite similar to the change of the value of environmental assets (cf. Figure 3b).

(4) NATURGY: In the reports we can find a description of all the environmental actions that the company has carried out, in addition to the amounts of its environmental investments (cf. Table 5).

Table 5. Environmental investments of the NATURGY group [millions of euro]

\begin{tabular}{llllllllllll}
\hline & $\mathbf{2 0 0 8}$ & $\mathbf{2 0 0 9}$ & $\mathbf{2 0 1 0}$ & $\mathbf{2 0 1 1}$ & $\mathbf{2 0 1 2}$ & $\mathbf{2 0 1 3}$ & $\mathbf{2 0 1 4}$ & $\mathbf{2 0 1 5}$ & $\mathbf{2 0 1 6}$ & $\mathbf{2 0 1 7}$ & Average \\
\hline $\begin{array}{l}\text { Environmental } \\
\text { assets }\end{array}$ & 46 & 109 & 40 & 58 & 46 & 36 & 33 & 24 & 21 & 17 & 43 \\
\hline $\begin{array}{l}\text { Total fixed } \\
\text { assets }\end{array}$ & 9,988 & 24,683 & 23,206 & 22,744 & 22,306 & 21,411 & 24,267 & 23,693 & 23,627 & 22,654 & 17,494 \\
\hline \% & 0.46 & 0.44 & 0.17 & 0.26 & 0.21 & 0.17 & 0.14 & 0.10 & 0.09 & 0.08 & 0.25 \\
\hline Total assets & 18,765 & 45,352 & 36,185 & 35,922 & 46,667 & 44,945 & 50,328 & 48,132 & 47,114 & 47,322 & 42,073 \\
\hline$\%$ & 0.25 & 0.24 & 0.11 & 0.16 & 0.10 & 0.08 & 0.07 & 0.05 & 0.04 & 0.04 & 0.10 \\
\hline
\end{tabular}

Source: own elaboration. 


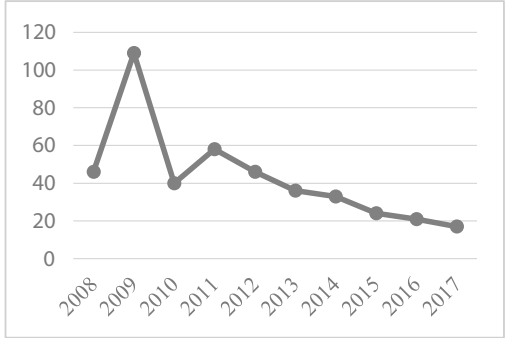

(a)

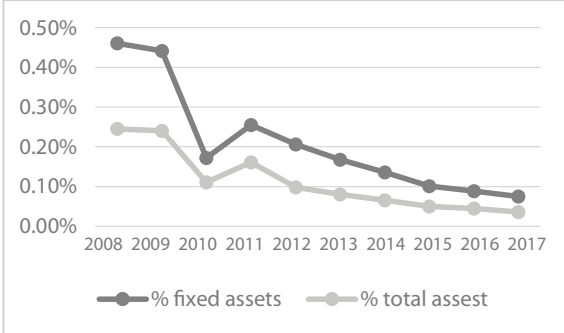

(b)

Figure 4. (a) Environmental assets of NATURGY [millions of euro];

(b) Environmental assets as percentages of fixed assets and total assets of NATURGY Source: own elaboration.

Analysing the evolution of the amounts of environmental assets, the general trend is decreasing, although there is a specific peak of growth in 2009 (cf. Figure 4a). Much more significant is the drop in the percentages of this investment in relation to the company's total fixed assets (cf. Figure 4b). As can be seen in the graph, the decline is significant and constant over the years. Practically the same downward curve is observed if we represent the relationship between environmental assets and total assets (cf. Figure 4b).

(5) IBERDROLA: This company does not report on specific amounts of financial resources dedicated to environmental investments. Due to this, we cannot calculate the investment trend of this company.

(6) AUDAX: The company does not provide any data regarding environmental investments. Therefore, it is not possible to carry out any type of analysis.

(7) SOLARIA: This company explains that it has adopted the appropriate measures in relation to the protection and improvement of the environment and the mitigation, where appropriate, of the environmental impact, complying with current regulations in this regard. It also reports that it has not made any environmental investments in the studied period. 


\section{Definition and registration of environmental expenses}

Similarly to the analysis of environmental assets, we have checked the regulations regarding environmental costs. According to the Resolution of the ICAC (2002):

The nature of environmental expenses will be the amounts accrued, from the environmental activities carried out or to be carried out, for the management of the environmental effects of the Entity's operations, as well as those derived from the environmental commitments of the accounting subject. Among them are the expenses caused by the prevention of pollution related to current operational activities, waste and spillage treatment, decontamination, restoration, environmental management or environmental auditing (ICAC, 2002, p. 12832).

According to the European Commission "only identifiable additional costs whose main purpose is to avoid, reduce or repair damage to the environment should only be included in this definition" (European Union Commission (CUE), 2001, p. 36). The amount of all those environmental expenses derived from the aforementioned activities will be considered as "operating expenses for the year in which they accrue and will be incorporated in the profit and loss account in the corresponding item; when its amount is significant, a specific item will be created with the name 'Environmental expenses' within the group 'Other operating expenses”’ (ICAC, 2002, p. 12833).

\section{Environmental expenses in the companies under the study}

Similarly as it has been done with the assets, we have studied how companies define environmental expenses and registration criteria used. The source of the definitions is the annual report of each company. Companies either do not provide any definition or criteria or briefly use the definition of environmental expenses provided by the ICAC Resolution (2002). All the companies considered these expenses as expenses for the year and none of them generated specific accounts (cf. Table 6). 
Table 6. Treatment of information on environmental expenses of companies

\begin{tabular}{lccc}
\hline & Definition & $\begin{array}{l}\text { Criteria for } \\
\text { recognition }\end{array}$ & Annual amounts \\
\hline REPSOL & & & $\mathrm{x}$ \\
\hline ENAGAS & & $\mathrm{x}$ & $\mathrm{x}$ \\
\hline ENDESA & $\mathrm{x}$ & $\mathrm{x}$ & $\mathrm{x}$ \\
\hline NATURGY & $\mathrm{x}$ & $\mathrm{x}$ & $\mathrm{x}$ \\
\hline IBERDROLA & $\mathrm{x}$ & $\mathrm{x}$ & $\mathrm{x}$ \\
\hline AUDAX & & & \\
\hline SOLARIA & $\mathrm{x}$ & $\mathrm{x}$ & \\
\hline
\end{tabular}

Source: own elaboration

To complete the study, we have established comparison with the amount of the turnover and total operating costs and thus we have calculated the percentage representing environmental expenses compared to the total of these amounts, making the information comparable between companies.

(1) REPSOL: The business group reports in its consolidated annual report on the expenses it has borne related to the environment, although the profit and loss account is integrated with other operating expenses (cf. Table 7).

Table 7. Environmental expenses of the REPSOL group [millions of euro]

\begin{tabular}{llllllllllll}
\hline & $\mathbf{2 0 0 8}$ & $\mathbf{2 0 0 9}$ & $\mathbf{2 0 1 0}$ & $\mathbf{2 0 1 1}$ & $\mathbf{2 0 1 2}$ & $\mathbf{2 0 1 3}$ & $\mathbf{2 0 1 4}$ & $\mathbf{2 0 1 5}$ & $\mathbf{2 0 1 6}$ & $\mathbf{2 0 1 7}$ & Average \\
\hline $\begin{array}{l}\text { Environmental } \\
\text { expenses }\end{array}$ & 363 & 347 & 356 & 392 & 202 & 164 & 128 & 170 & 155 & 162 & 243.9 \\
\hline Sales & 57,740 & 45,827 & 53,663 & 60,122 & 57,193 & 54,683 & 45,433 & 39,582 & 34,556 & 41,242 & 49,004 \\
\hline \% & 0.63 & 0.76 & 0.66 & 0.65 & 0.35 & 0.30 & 0.28 & 0.43 & 0.45 & 0.39 & 0.50 \\
\hline $\begin{array}{l}\text { Operating } \\
\text { expenses }\end{array}$ & 55,892 & 45,788 & 52,809 & 58,927 & 55,307 & 53,727 & 47,214 & 44,181 & 35,522 & 40,659 & 49,003 \\
\hline$\%$ & 0.65 & 0.76 & 0.67 & 0.67 & 0.37 & 0.31 & 0.27 & 0.38 & 0.44 & 0.40 & 0.50 \\
\hline
\end{tabular}

Source: own elaboration.

The company's environmental expenses have decreased significantly between 2008 and 2014, stabilizing in 2015-2017 (cf. Figure 5a). 


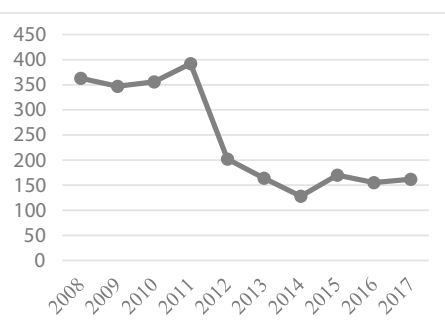

(a)

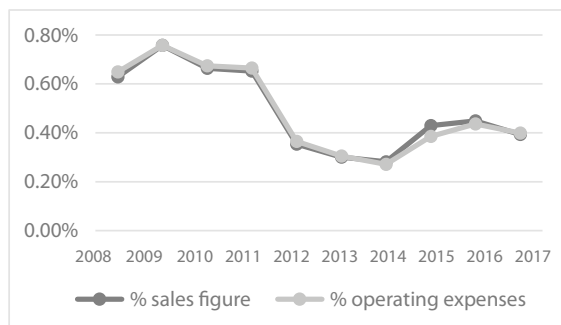

(b)

Figure 5. (a) REPSOL environmental expenses [millions of euro]; (b)

Environmental expenses as percentages of the sales figure and operating expenses of REPSOL

Source: own elaboration

The trend lines illustrating the comparison of REPSOL environmental expenses with the sales figure and with the total operating expenses behave in a very similar way to environmental expenses with a decreasing trend until 2014 and a stabilization in the following years (cf. Figure 5b).

(2) ENAGAS: This business group has increased its environmental expenses considerably over the 10 years analyzed (cf. Table 8).

Table 8. Environmental expenses of ENAGAS [thousands of euro]

\begin{tabular}{llllllllllll}
\hline & $\mathbf{2 0 0 8}$ & $\mathbf{2 0 0 9}$ & $\mathbf{2 0 1 0}$ & $\mathbf{2 0 1 1}$ & $\mathbf{2 0 1 2}$ & $\mathbf{2 0 1 3}$ & $\mathbf{2 0 1 4}$ & $\mathbf{2 0 1 5}$ & $\mathbf{2 0 1 6}$ & $\mathbf{2 0 1 7}$ & Average \\
\hline $\begin{array}{l}\text { Environmental } \\
\text { expenses }\end{array}$ & 749 & 852 & 1,198 & 914 & 922 & 924 & 1,346 & 1,468 & 1,853 & 2,422 & 1,265 \\
\hline Sales & 813,101 & 866,829 & 965,995 & $1,096,280$ & $1,180,059$ & $1,278,603$ & $1,206,192$ & $1,196,366$ & $1,187,994$ & $1,360,170$ & $1,115,159$ \\
\hline$\%$ & 0.09 & 0.10 & 0.12 & 0.08 & 0.08 & 0.07 & 0.11 & 0.12 & 0.16 & 0.18 & 0.11 \\
\hline $\begin{array}{l}\text { Operating } \\
\text { expenses }\end{array}$ & 427,129 & 416,770 & 469,677 & 568,837 & 579,976 & 639,254 & 637,564 & 619,636 & 606,999 & 725,361 & 569,120 \\
\hline$\%$ & 0.18 & 0.20 & 0.26 & 0.16 & 0.16 & 0.14 & 0.21 & 0.24 & 0.31 & 0.33 & 0.22 \\
\hline
\end{tabular}

Source: own elaboration

The following Figure 6a clearly shows the growing trend of expenses, experiencing a sharp rise from 2013. If compared with sales and operating expenses, the trend line visualising the company's environmental expenses is clearly increasing (cf. Figure 6b). 


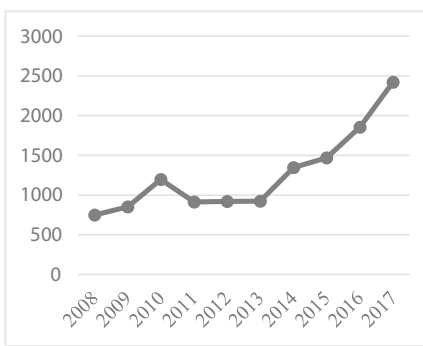

(a)

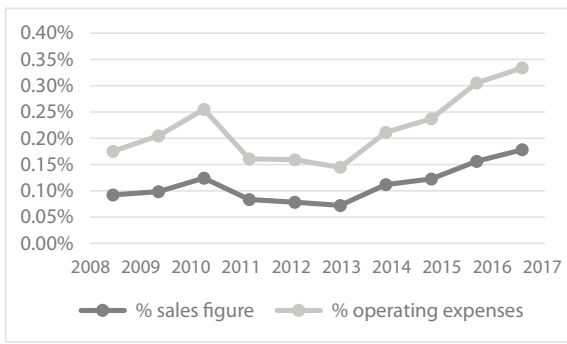

(b)

Figure 6. (a) Environmental expenses of ENAGAS [thousands of euro];

(b) Environmental expenses as percentages of the sales figure and operating expenses of ENAGAS

Source: own elaboration.

(3) ENDESA: The company's' environmental expenses were increasing considerably until 2012, after which the amounts began to fall. This trend changed in 2017, when a slight rise was noticed (cf. Table 9 and Figure 7a).

Table 9. Environmental expenses of ENDESA [millions of euro]

\begin{tabular}{llllllllllll}
\hline & $\mathbf{2 0 0 8}$ & $\mathbf{2 0 0 9}$ & $\mathbf{2 0 1 0}$ & $\mathbf{2 0 1 1}$ & $\mathbf{2 0 1 2}$ & $\mathbf{2 0 1 3}$ & $\mathbf{2 0 1 4}$ & $\mathbf{2 0 1 5}$ & $\mathbf{2 0 1 6}$ & $\mathbf{2 0 1 7}$ & Average \\
\hline $\begin{array}{l}\text { Environmental } \\
\text { expenses }\end{array}$ & - & 37 & 38 & 138 & 142 & 130 & 118 & 99 & 80 & 100 & 98 \\
\hline Sales figure & 21,728 & 24,433 & 29,558 & 30,827 & 32,284 & 29,677 & 20,473 & 19,281 & 18,313 & 19,556 & 24,613 \\
\hline$\%$ & - & 0.15 & 0.13 & 0.45 & 0.44 & 0.44 & 0.58 & 0.51 & 0.44 & 0.51 & 0.40 \\
\hline $\begin{array}{l}\text { Operating } \\
\text { expenses }\end{array}$ & 15,941 & 18,464 & 23,703 & 25,421 & 26,928 & 24,483 & 18,422 & 17,260 & 15,547 & 16,515 & 20,268 \\
\hline$\%$ & - & 0.20 & 0.16 & 0.54 & 0.53 & 0.53 & 0.64 & 0.57 & 0.51 & 0.61 & 0.48 \\
\hline
\end{tabular}

Source: own elaboration.

If we analyse the comparison of environmental expenses with the sales and operating expenses figures, the trend of the curve changes, showing a marked rise until 2011 and a slight rise in the remaining part of the analysed period, against the fall in absolute amounts. This is due to a decrease in the total expense sales amounts (cf. Figure 7). The general trend is therefore upward (cf. Figure 7b), which means that environmental aspects have been gaining a greater presence in the expense structure. 


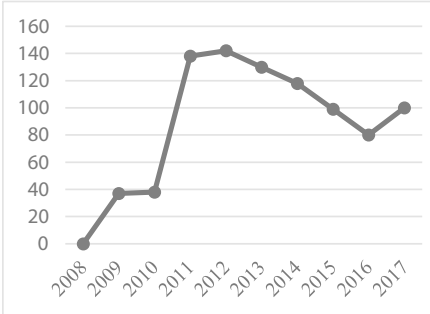

(a)

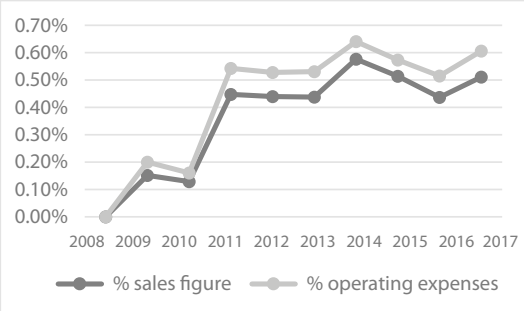

(b)

Figure 7. (a) Environmental expenses of ENDESA [millions of euro];

(b) Environmental expenses as percentages of the sales figure and operating expenses of ENDESA

Source: own elaboration.

(4) NATURGY: The company's amounts of environmental expenses have been clearly increasing (cf. Table 10 and Figure 8a).

Table 10. Environmental expenses of NATURGY [millions of euro]

\begin{tabular}{llllllllllll}
\hline & $\mathbf{2 0 0 8}$ & $\mathbf{2 0 0 9}$ & $\mathbf{2 0 1 0}$ & $\mathbf{2 0 1 1}$ & $\mathbf{2 0 1 2}$ & $\mathbf{2 0 1 3}$ & $\mathbf{2 0 1 4}$ & $\mathbf{2 0 1 5}$ & $\mathbf{2 0 1 6}$ & $\mathbf{2 0 1 7}$ & Average \\
\hline $\begin{array}{l}\text { Environmental } \\
\text { expenses }\end{array}$ & - & 24 & 31 & 42 & 59 & 44 & 65 & 71 & 70 & 79 & 53.89 \\
\hline Sales figure & 13,544 & 14,879 & 19,630 & 21,076 & 24,904 & 24,969 & 24,697 & 26,015 & 21,908 & 23,306 & $21,492.80$ \\
\hline \% & - & 0.16 & 0.16 & 0.20 & 0.24 & 0.18 & 0.26 & 0.27 & 0.32 & 0.34 & 0.25 \\
\hline $\begin{array}{l}\text { Operating } \\
\text { expenses }\end{array}$ & 11,845 & 12,651 & 17,396 & 18,693 & 22,141 & 22,270 & 22,065 & 23,080 & 17,576 & 19,694 & $18,741.10$ \\
\hline$\%$ & - & 0.19 & 0.18 & 0.22 & 0.27 & 0.20 & 0.29 & 0.31 & 0.40 & 0.40 & 0.29 \\
\hline
\end{tabular}

Source: own elaboration.

In the comparison with sales and operating expenses, the change is similar, obtaining an increasing trend very similar to that seen in environmental expenses (cf. Figure 8a). The general trend of the company shows a greater presence of environmental expenses in its expense account (cf. Figure 8b).

(5) IBERDROLA: This company does not report on specific amounts dedicated to environmental expenses, but it does explain the actions it carries out in the environmental field. 


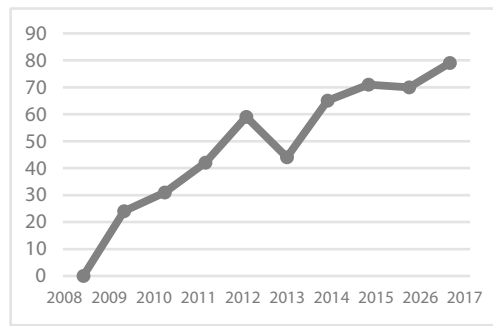

(a)

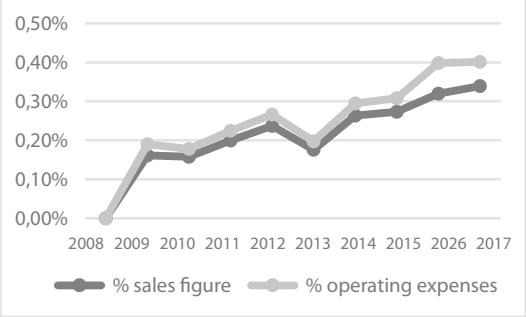

(b)

Figure 8. (a) Environmental expenses of NATURGY [millions of euro];

(b) Environmental expenses as percentages of the sales figure and operating expenses of NATURGY

Source: own elaboration.

(6) AUDAX: Although the company does not provide information on environmental investments, it does provide information on expenses dedicated to the environment (cf. Table 11).

Table 11. Environmental expenses of the AUDAX group [thousands of euro]

\begin{tabular}{llllllllllll}
\hline & $\mathbf{2 0 0 8}$ & $\mathbf{2 0 0 9}$ & $\mathbf{2 0 1 0}$ & $\mathbf{2 0 1 1}$ & $\mathbf{2 0 1 2}$ & $\mathbf{2 0 1 3}$ & $\mathbf{2 0 1 4}$ & $\mathbf{2 0 1 5}$ & $\mathbf{2 0 1 6}$ & $\mathbf{2 0 1 7}$ & average \\
\hline $\begin{array}{l}\text { Environmental } \\
\text { expenses }\end{array}$ & 214 & 189 & 216 & 200 & 209 & 116 & 110 & 111 & 116 & 120 & 160.1 \\
\hline Sales figure & 20,242 & 21,415 & 30,100 & 43,009 & 44,646 & 37,866 & 25,622 & 28,477 & 30,168 & 36,891 & $31,843.6$ \\
\hline \% & 1.06 & 0.88 & 0.72 & 0.47 & 0.47 & 0.31 & 0.43 & 0.39 & 0.38 & 0.33 & 0.50 \\
\hline $\begin{array}{l}\text { Operating } \\
\text { expenses }\end{array}$ & 15,830 & 19,256 & 79,719 & 179,945 & 114,793 & 27,232 & 21,210 & 35,014 & 58,285 & 23,644 & $57,492.8$ \\
\hline$\%$ & 1.35 & 0.98 & 0.27 & 0.11 & 0.18 & 0.43 & 0.52 & 0.32 & 0.20 & 0.51 & 0.28 \\
\hline
\end{tabular}

Source: own elaboration.

Figure 9a shows a downward trend in environmental expenses of the AUDAX company until 2013 with a subsequent stabilization of the amounts. Analysing environmental expenses as the percentage of the sales figure, the trend is downward. However, while compared with operating costs, the changes of environmental expenses are more fluctuating. A descending period (2008-2011) is followed by an ascending period (2012-2014). Then, a new decline (2015-2016) is noticed and finally a rise in 2017 is reported. In any case, the trend marks a general decline (cf. Figure 9). 


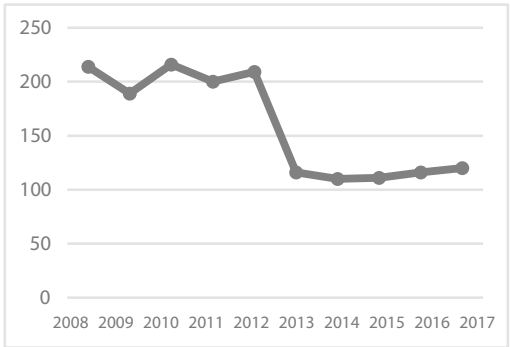

(a)

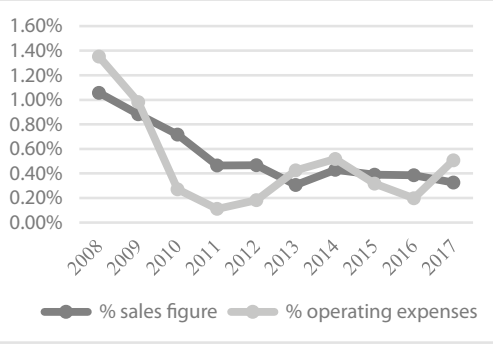

(b)

Figure 9. (a) Environmental expenses of AUDAX [thousands of euro];

(b) Environmental expenses as percentages of the sales figure and operating expenses of AUDAX

Source: own elaboration.

(7) SOLARIA: This business group does not provide any information on environmental assets or expenses in any of the documents analyzed.

\section{Results: Comparative study among the companies}

In general, all the companies under the study explain in the reports their main environmental investments and projects they carry out, providing economic data and qualitative data. In addition, they usually add epigraphs referring to climate change, circular economy, sustainable energy, biodiversity, but they also inform about spills, emissions, residues, accidents and prevention actions. Generally, they indicate that for more information corporate responsibility reports or sustainability reports should be consulted (cf. Table 12).

Table 12. Type of environmental information present in the reports

\begin{tabular}{llllll}
\hline & $\begin{array}{l}\text { Environmental } \\
\text { assets }\end{array}$ & $\begin{array}{l}\text { Environmental } \\
\text { expenses }\end{array}$ & Biodiversity & Waste & $\begin{array}{l}\text { Circular } \\
\text { economy }\end{array}$ \\
\hline REPSOL & $\begin{array}{l}\text { Info Qualitative } \\
\text { Amounts }\end{array}$ & Amounts & Info Qualitative & Info qualitative & Info qualitative \\
\hline ENAGAS & Amounts & Amounts & & \\
\hline ENDESA & Amounts & Amounts & & Info Qualitative \\
\hline NATURGY & $\begin{array}{l}\text { Qualitative info } \\
\text { Amounts }\end{array}$ & Amounts & Info Qualitative & \\
\hline
\end{tabular}


Table 12. Continued

\begin{tabular}{|c|c|c|c|c|c|}
\hline & $\begin{array}{l}\text { Environmental } \\
\text { assets }\end{array}$ & $\begin{array}{l}\text { Environmental } \\
\text { expenses }\end{array}$ & Biodiversity & Waste & $\begin{array}{l}\text { Circular } \\
\text { economy }\end{array}$ \\
\hline IBERDROLA & Does not have & Does not have & Info Qualitative & & \\
\hline AUDAX & Does not have & Amounts & Info Qualitative & & \\
\hline SOLARIA & Does not have & Does not have & & & \\
\hline
\end{tabular}

Source: own elaboration

In order to compare and contrast the amounts of environmental assets in the studied companies, we have analysed their environmental assets as the percentage of fixed assets (cf. Table 13).

Table 13. Percentages of environmental assets with respect to fixed assets

\begin{tabular}{llllllllllll}
\hline & $\mathbf{2 0 0 8}$ & $\mathbf{2 0 0 9}$ & $\mathbf{2 0 1 0}$ & $\mathbf{2 0 1 1}$ & $\mathbf{2 0 1 2}$ & $\mathbf{2 0 1 3}$ & $\mathbf{2 0 1 4}$ & $\mathbf{2 0 1 5}$ & $\mathbf{2 0 1 6}$ & $\mathbf{2 0 1 7}$ & Average \\
\hline REPSOL & 11.37 & 9.80 & 9.73 & 10.30 & 9.61 & 10.88 & 17.16 & 11.05 & 11.82 & 13.50 & 11.15 \\
\hline ENAGAS & 1.37 & 0.75 & 0.76 & 0.42 & 0.39 & 0.16 & 0.16 & 0.57 & 0.22 & 0.10 & 0.46 \\
\hline ENDESA & - & 0.06 & 0.06 & 0.12 & 0.21 & 0.27 & 0.54 & 0.40 & 0.49 & 0.51 & 0.26 \\
\hline NATURGY & 0.46 & 0.44 & 0.17 & 0.26 & 0.21 & 0.17 & 0.14 & 0.10 & 0.09 & 0.08 & 0.25 \\
\hline IBERDROLA & - & - & - & - & - & - & - & - & - & - & - \\
\hline AUDAX & - & - & - & - & - & - & - & - & - & - & - \\
\hline SOLARIA & - & - & - & - & - & - & - & - & - & - & - \\
\hline
\end{tabular}

Source: own elaboration.

We can clearly verify that the REPSOL company is the one that carries out the most environmental investments, which makes it different comparing to other companies under the study (cf. Figure 10).

In order to better recognize the trends in the other companies, we have provided a graphical representation of their environmental investments. There is one company, i.e. ENDESA, with a positive trend and the other two with negative trends. The values of environmental assets calculated as the percentage of fixed assets in the analysed companies are between $0.1 \%$ and $0.6 \%$ (cf. Figure 11 ).

Regarding environmental expenses, in order to compare the data between companies, we have used the values of environmental expenses calculated as the percentages of operating expenses (cf. Table 14). 


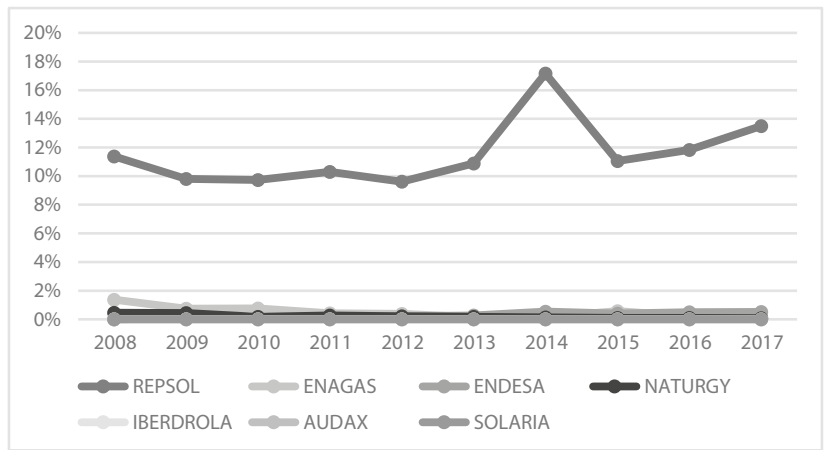

Figure 10. Environmental assets as the percentage of fixed assets Source: own elaboration.

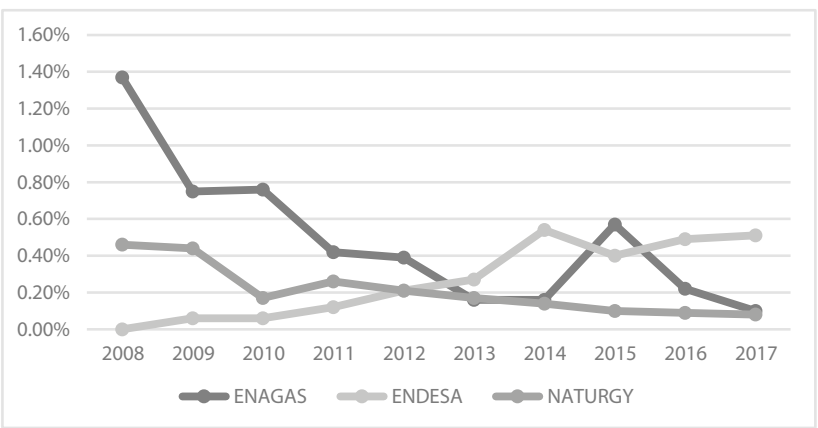

Figure 11. Environmental assets as the percentage of fixed assets of ENAGAS, ENDESA and NATURGY

Source: own elaboration.

Table 14. Environmental expenses as the percentage of operating expenses

\begin{tabular}{llllllllllll}
\hline & $\mathbf{2 0 0 8}$ & $\mathbf{2 0 0 9}$ & $\mathbf{2 0 1 0}$ & $\mathbf{2 0 1 1}$ & $\mathbf{2 0 1 2}$ & $\mathbf{2 0 1 3}$ & $\mathbf{2 0 1 4}$ & $\mathbf{2 0 1 5}$ & $\mathbf{2 0 1 6}$ & $\mathbf{2 0 1 7}$ & Average \\
\hline REPSOL & 0.65 & 0.76 & 0.67 & 0.67 & 0.37 & 0.31 & 0.27 & 0.38 & 0.44 & 0.40 & 0.50 \\
\hline ENAGAS & 0.18 & 0.20 & 0.26 & 0.16 & 0.16 & 0.14 & 0.21 & 0.24 & 0.31 & 0.33 & 0.22 \\
\hline ENDESA & - & 0.20 & 0.16 & 0.54 & 0.53 & 0.53 & 0.64 & 0.57 & 0.51 & 0.61 & 0.48 \\
\hline NATURGY & - & 0.19 & 0.18 & 0.22 & 0.27 & 0.20 & 0.29 & 0.31 & 0.40 & 0.40 & 0.29 \\
\hline IBERDROLA & - & - & - & - & - & - & - & - & - & - & - \\
\hline AUDAX & 1.35 & 0.98 & 0.27 & 0.11 & 0.18 & 0.43 & 0.52 & 0.32 & 0.20 & 0.51 & 0.28 \\
\hline SOLARIA & - & - & - & - & - & - & - & - & - & - & - \\
\hline
\end{tabular}

Source: own elaboration. 
The environmental expenses of the companies in 2008-2012 were very differentiated. Then, since 2013, an increasing trend has been observed. The amounts have been homogenizing, rising to a range of values between $0.2 \%$ and $0.6 \%$, very similar to that established in the comparison of environmental assets (cf. Figure 12).

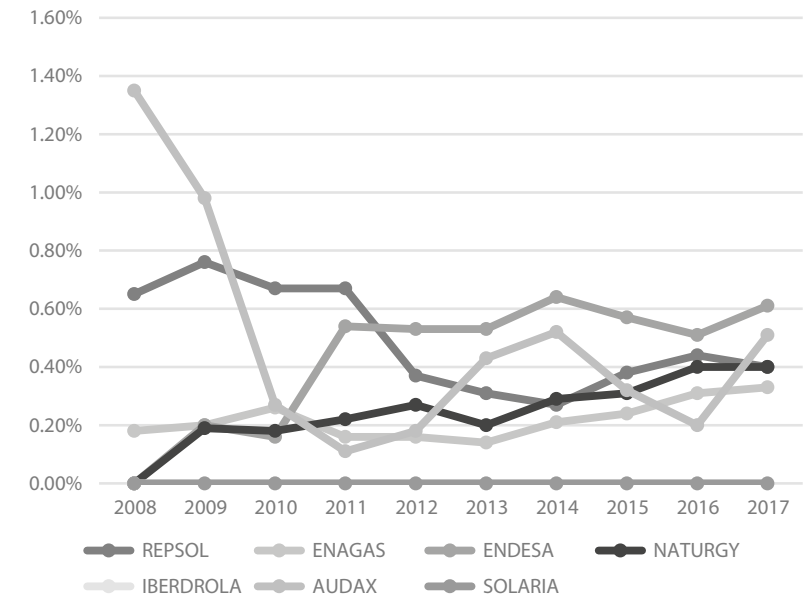

Figure 12. Environmental expenses as the percentage of operating expenses

Source: own elaboration.

Considering the data, differentiation between subsectors may be observed. The oil sector seems to be the leader in environmental investments among the studied companies. Simultaneously, energy companies show a slightly increasing trend in recent years. It is striking that the two companies operating in the renewable energy subsector provide the least environmental information in their reports. However, Huang and Watson (2015) and Larrán Jorge and Andrades Peña (2015) indicate in their studies that companies that operate with renewable energies collect and disseminate lower levels of systematic information, which is also true in this specific study.

Lasierra Asún (2019) affirms that the sector seems to be making more and more efforts to provide its services efficiently and with less environmental impact and, according to the study by Domínguez Churruca (2014), Spanish energy companies did not publish enough environmental information although the trend is positive. Also, Serrat and Aliberch (2010) conclude that only $48 \%$ of the companies analyzed 
presented environmental information in the annual accounts. Regarding corporate social responsibility, according to Toribios Plaza (2019), there is a positive relationship between the performance of CSR activities by organisations and their corporate image. González Bonilla (2017) concludes that the publications that have reached the greatest number of public have been those related to the environmental and social field (61.1\% users surveyed), which reveals the importance of the publication of environmental information and their positive effect, an issue that we consider essential in this article. Finally, Vicuña et al. (2020) state that, although environmental accounting by itself is not enough to exercise control over environmental responsibility, it is a good tool to record and report on the activity of companies in favor of the environment. Therefore, we consider that the results obtained are in line with previous studies on social responsibility and environmental accounting in the Spanish energy sector.

\section{Conclusions}

The first objective of the study was to verify that current financial accounting is not capable of reporting, through its financial statements, the relationships that the company has with the environment. It is concluded that the expenses or investments by companies to prevent contamination or improving the environment, usually are recorded in accounting, but not specifically classified as an environment expense or an environment asset, so these items are overlooked, because they are scattered across different accounts. The balance sheet and the income statement do not show environmental information. To consult this information, it is needed to use annual reports, management reports, corporate responsibility reports or sustainability reports.

The second objective of the study was to verify the changes in environmental assets and expenses in the analysed companies. Regarding the studied companies, environmental assets and expenses are still insufficient, although there is a slight positive trend in all of them. This may be mainly due to a weak involvement of the companies in caring for the environment, or inadequate records of environmental activities. It would be desirable to improve the criteria for identifying and evaluating environmental items applicable at a general level. This homogenization of criteria would significantly contribute to environ- 
mental social responsibility, making companies more transparent and sustainable.

The third objective was to find if the company can use this information effectively for decision-making, developing an appropriate corporate social responsibility strategy in its environmental line. Regarding this objective, we must conclude, that traditional accounting does not have adequate tools to enable executives to implement environmental policies of corporate social responsibility. The notes in the annual report are insufficient, not providing relevant and quality information for users. Those organisations that invest in environmental protection and are transparent, could achieve some benefits such as improved reputation and corporate image, reduce potential risks associated with bad practices, promote innovation, or improve energy efficiency, among others. A possible future line of research could be the relationship between investment and environmental spending and the impact it produces on these possible benefits or a cost-benefit analysis of the applied environmental CSR measures.

This study is the starting point for exploring energy companies regarding the publication and accounting records of their environmental information, connecting concepts such as environmental accounting and social responsibility. Thus, it provides insights for a possible incorporation of these tools that would allow improvement of environmental management in these organizations.

The research has certain limitations such as the small number of companies that makes any statistical analysis difficult. To overcome this limitation, it could be extended to international companies, or to the rest of Spanish companies in the same sector. It would also be good to investigate the use of environmental information in decisionmaking processes, through a questionnaire survey to be completed by companies. Another limitation is a lack of legal obligation to present information on environmental assets and expenses by some of companies, which makes any comparison and analysis difficult.

\section{References}

AUDAX RENOVABLES (2008-2017). Annual Reports. Retrieved from: https:// www.cnmv.es/Portal/Consultas/IFA/ListadoIFA.aspx?id=0\&fechaDesde=01/01/20 08\&fechaHasta=31/12/2018\&nif=A62338827 (accessed 17 July 2018).

Cajiga, J. (2013). El concepto de responsabilidad social empresarial. México: I.CEMEF. 
Comisión de la Unión Europea (CUE) (2001). Recomendación de la Comisión de 30 de mayo de 2001 relativa al reconocimiento, la medición y la publicación de las cuestiones medioambientales en las cuentas anuales y los informes anuales de las empresas, Diario Oficial de las Comunidades Europeas.

Domínguez Churruca, P. (2014). Importancia de la contabilidad medioambiental en el sector energético español: Rasgos y evolución. Madrid: Universidad Pontifica de Comillas.

ENAGAS S.A (2008-2017). Annual Reports. Retrieved from: https://www.cnmv. es/Portal/Consultas/IFA/ListadoIFA.aspx?id=0\&fechaDesde=01/01/2008\& fechaHasta=31/12/2018\&nif=A-28294726 (accessed 19 July 2018).

ENDESAS.A.(2008-2017).Annual Reports. Retrieved from:https://www.cnmv.es/Portal/ Consultas/IFA/ListadoIFA.aspx?id=0\&fechaDesde=01/01/2008\&fechaHasta=31 /12/2018\&nif=A-28023430 (accessed 22 July 2018).

Garcia Garcia, P. J. (2014). Análisis de las memorias de sostenibilidad del sector energético español (Doctoral Dissertation). Valencia: Universidad Politécnica de Valencia.

González Bonilla, J. (2017). La comunicación de la Responsabilidad Social Corporativa del sector energético español en los medios sociales y su percepción en los públicos. Madrid: Universidad Complutense de Madrid.

Guevara, A. \& Galvis, M. (2019). Una mirada a la contabilidad ambiental en Colombia desde las perspectivas del desarrollo sostenible. Revista Facultad de Ciencias Económicas, 27(1), 87-106.

Huang, X. B. \& Watson, L. (2015). Corporate social responsibility research in accounting. Journal of Accounting Literature, 34, 1-16.

IBERDROLA S.A. (2008-2017). Annual Reports. Retrieved from: https://www.cnmv. es/Portal/Consultas/IFA/ListadoIFA.aspx?id=0\&fechaDesde=01/01/2008\&fecha Hasta=31/12/2018\&nif=A-48010615 (accessed 21 July 2018).

ICAC (2002). Resolución de 25/03/2002 por la que se aprueban normas para el reconocimiento, valoración e información de los aspectos medioambientales en las cuentas anuales. Retrieved from: https://www.boe.es/boe/dias/2002/04/04/pdfs/A1 2831-12834.pdf (accessed 2 September 2018).

Larrán Jorge, M. \& Andrades Peña, F. (2015). La oferta de asignaturas de responsabilidad social corporativa y ética empresarial en las titulaciones de finanzas y contabilidad: Análisis comparativo con el ámbito de la gestión de organizaciones. Revista de Contabilidad, 18(1), 1-10.

Lasierra Asún, D. (2019). Un análisis de la Responsabilidad Social Corporativa en el sector energético español: cómo se presenta, cómo se percibe (Master Thesis). Madrid: Universidad Nacional de Educación a Distancia.

Mejia Soto, E. (2010). Contabilidad Ambiental, Crítica al Modelo de Contabilidad Financiera. Armenia: Universidad del Quindío.

NATURGY ENERGY GROUP S.A. (2008-2017). Annual Reports. Retrieved from: https://www.cnmv.es/Portal/Consultas/IFA/ListadoIFA.aspx?id=0\&fechaDesde $=01 / 01 / 2008 \&$ fechaHasta=31/12/2018\&nif=A-08015497 (accessed 21 July 2018).

Pérez Espinoza, M., Espinoza Carrión, C. \& Peralta Mocha, B. (2016). La responsabilidad social empresarial y su enfoque ambiental: una visión sostenible a futuro. Revista Universidad y Sociedad, 8(3),169-178. 
REPSOL S.A. (2008-2017). Annual Reports. Retrieved from: https://www.cnmv.es/ Portal/Consultas/IFA/ListadoIFA.aspx id $=0 \&$ fechaDesde $=01 / 01 / 2008 \&$ fecha Hasta=31/12/2018\&nif=A-78374725 (accessed 2 July 2018).

Serrat, N., \& Aliberch, A. (2010). Análisis de la responsabilidad social corporativa, en su aspecto medioambiental, en empresas del mercado continuo Español. XIV Encuentro AECA, Información Financiera de Calidad: Señalando el Camino de la Recuperación. Coruña.

SOLARIA ENERGIA Y MEDIOAMBIENTE S.A. (2008-2017). Annual Reports. Retrieved from: https://www.cnmv.es/Portal/Consultas/IFA/ListadoIFA.aspx?id= 0\&fechaDesde $=01 / 01 / 2008 \&$ fechaHasta $=31 / 12 / 2018 \&$ nif $=$ A83511501 (accessed 03 July 2018).

Toribios Plaza, R. (2019). La RSC y la imagen de marca en el sector energético en España. Valladolid: Universidad de Valladolid.

Vicuña, R. K. A., Zurita, I. N., \& Álvarez, J. C. E. (2020). La contabilidad ambiental y su contribución en la responsabilidad social empresarial. Dominio de las Ciencias, 6(1), 68-98. 
